\title{
Hay intake improves performance and rumen development of calves fed higher quantities of milk
}

\author{
M. A. Khan, D. M. Weary, and M. A. G. von Keyserlingk ${ }^{1}$ \\ Animal Welfare Program, University of British Columbia, 2357 Mall, Vancouver, BC, Canada, V6T 1 Z4
}

ABSTRACT

Research to date has suggested that access to forage before weaning can limit rumen development in calves, but no research has yet addressed the role of forage for calves fed higher quantities of milk. This study compared performance and rumen development of calves provided high volumes (equivalent to approximately $20 \%$ of calf birth weight) of milk with and without access to hay. At d 3 of age, individually housed calves were randomly assigned to treatment (either ad libitum access to chopped grass hay or no forage; $\mathrm{n}=15$ calves per treatment, 10 heifers, and 5 bulls). All calves were provided ad libitum access to water and starter throughout the study. All calves were offered $8 \mathrm{~L}$ of milk/d from a nipple bottle from d 3 to $35,4 \mathrm{~L} / \mathrm{d}$ from d 36 to 53 , and $2 \mathrm{~L} / \mathrm{d}$ until weaning at d 56 . Solid feed intake and growth parameters were monitored from $\mathrm{d}$ 3 to 70 . At d 70, males from both treatments were slaughtered to measure rumen development parameters. Overall dry matter (DM) intake from solid feed did not differ between treatments before wk 5 . However, during wk 6 to 10, calves fed forage consumed more total DM (starter plus hay) than did calves fed no forage. Hip and wither height, heart girth, and body barrel at $\mathrm{d} 3$, 56 , and 70 did not differ between treatments. Reticulorumen weight was heavier in calves fed hay versus those fed only starter $(12.77 \pm 1.29$ vs. $7.99 \pm 0.69 \mathrm{~kg}$ with digesta; $1.89 \pm 0.05$ vs. $1.60 \pm 0.09 \mathrm{~kg}$ without digesta). Body weight without digesta was similar in calves fed forage or no forage. Mean rumen $\mathrm{pH}$ was higher in calves fed hay compared with those fed no forage $(5.49 \pm 0.08$ vs. $5.06 \pm 0.04)$. In conclusion, provision of chopped hay to calves fed high volumes of milk can promote solid feed DM intake and rumen development without affecting BW gain.

Key words: forage, weaning, rumen development, accelerated growth

\footnotetext{
Received September 28, 2010.

Accepted March 13, 2011.

${ }^{1}$ Corresponding author: marina.vonkeyserlingk@ubc.ca
}

\section{INTRODUCTION}

In dairy heifers separated from their dam immediately after birth and artificially reared, a smooth transition from liquid feed (milk or milk replacer) to solid feed (grains or forage) is key to minimizing mortality and morbidity losses related with diseases, and increasing daily weight gains (Drackley, 2008). Conventional feeding provides a limited supply of milk (typically $10 \%$ of BW/d) to calves with the aim of encouraging starter intake and promoting early rumen development and weaning, but research during the last decade has shown that feeding higher amounts of milk or milk replacer enhances growth rates, improves feed efficiency (Diaz et al., 2001; Jasper and Weary, 2002; Brown et al., 2005), and decreases the incidence of diseases (Khan et al., 2007a) and behavioral signs of hunger (De Paula Vieira et al., 2008). However, increased milk intake decreases intake of starter, and this lag in the initiation of solid feed intake could delay rumen development and retard growth at weaning (Jasper and Weary, 2002). Gradual weaning of high milk-fed calves can increase solid feed consumption (Sweeney et al., 2010), trigger rumen development (Khan et al., 2007a; Roth et al., 2008), and help improve energy intakes (de Passillé et al., 2010) to support greater BW gain during and after weaning (Khan et al., 2007a; Roth et al., 2009; Sweeney et al., 2010).

Introducing forage during the milk feeding period has long been discouraged, as the forage is thought to displace concentrate intake and shift rumen fermentation in favor of acetate rather than butyrate production and, thus, delay rumen papillae development (Tamate et al., 1962; Zitnan et al., 1998). Forage is less energy dense than calf starter feed, so inclusion of forage in the diets during the preweaning period results in poorer BW weight gains in calves fed restricted and low quantities of milk (Kertz et al., 1979; Hill et al., 2008a,b). However, studies to date have assessed the effects of forage on calves fed milk at approximately 4 to $5 \mathrm{~L} / \mathrm{d}$ (about $10 \%$ of calf birth weight). With increasing interest in feeding higher volumes of milk $(8$ to $10 \mathrm{~L} / \mathrm{d}$, or about $20 \%$ of birth weight) it is important to reexamine the effects of different solid feeds on growth and rumen 
development of calves. To our knowledge no research has addressed the effects of forage on DMI and growth for calves fed higher volumes of milk.

We hypothesized that, for calves fed milk at higher rates $(8 \mathrm{~L} / \mathrm{d}$, or about $20 \%$ of calf birth weight), provision of forage would have no detrimental effects on total intake of solid feed, but that provision of forage would result in a physically more developed rumen (because of greater mechanical stimulus). This study compared feed consumption, growth, and rumen development of calves provided high volumes of milk with and without access to hay.

\section{MATERIALS AND METHODS}

\section{Calves, Management, and Treatments}

This study was conducted at the UBC Dairy Education and Research Centre in Agassiz, BC, Canada. The Institutional Animal Care Committee (monitored according to CCAC, 2009) approved all procedures described in this study.

Holstein calves (20 heifers and 10 bulls) were separated from their mothers, weighed, and moved to individual pens $(1.2 \mathrm{~m} \times 2.0 \mathrm{~m})$, bedded with sawdust, and fed colostrum within $6 \mathrm{~h}$ after birth. Blood samples were collected from the jugular vein $24 \mathrm{~h}$ after the first feeding of colostrum, and serum total protein was determined using a Reichert AR 200 digital hand-held refractometer (Reichert, Inc., Depew, NY). Only calves having a serum protein level $>5.3 \mathrm{~g} / \mathrm{dL}$ and $\mathrm{BW}>36 \mathrm{~kg}$ at $\mathrm{d} 1$ were included in the study. Calves were sedated and dehorned at $5 \pm 1 \mathrm{~d}$ of age using caustic paste (see Vickers et al., 2005 for details). Fresh bedding was added to each pen twice per week and ad libitum access to clean water from a plastic bucket was made available throughout the experiment.

Calves were fed pasteurized waste and saleable milk $(3.2 \pm 0.25 \%$ protein, $3.72 \pm 0.24 \%$ fat, $4.2 \pm 0.06 \%$ lactose, and SCC of $857 \pm 372.6 \times 1,000 / \mathrm{mL})$ at approximately $38^{\circ} \mathrm{C}$ using plastic bottles $(\sim 2$-L capacity) fitted with rubber nipples according to step-down (gradual weaning) procedure (described previously by Khan et al., 2007a) to encourage solid feed intake within milk feeding period. Briefly, all calves were fed in 2 equal feedings (at 0800 and $1600 \mathrm{~h}$ ), $4 \mathrm{~L}$ of milk/d for the first $2 \mathrm{~d}$ of life, $8 \mathrm{~L} / \mathrm{d}$ from d 3 to $\mathrm{d} 35$ (wk $1-5)$ of age, $4 \mathrm{~L} / \mathrm{d}$ from d 36 to 53 , and $2 \mathrm{~L}$ of milk/d from d 54 to 56 . Milk feeding bottles were washed and disinfected with a $5 \%$ hypochloride solution after each feeding. All calves had ad libitum (at least 10\% refusal) access to a textured calf starter (contains on as is basis $57.5 \%$ concentrate pellets, $14 \%$ flatted barley, $13 \%$ flatted oats, $10 \%$ steamroll corn, and 3.5\% molasses; Unifeed Ltd., Chilliwack, BC, Canada).

At d 3, the calves were assigned alternatively to 1 of 2 treatments. In the control treatment $(\mathbf{S T} ; \mathrm{n}=15 ; 10$ heifers, 5 bulls), calves received no forage. In the forage treatment (STH; $\mathrm{n}=15 ; 10$ heifers, 5 bulls), calves were provided ad libitum access to chopped (mean particle size $=1.2 \pm 0.4 \mathrm{~cm}$; calculated using the Penn State Particle Separator; University Park, PA) orchard grass hay throughout the experiment.

The calves were observed daily for any sign of illness (nasal discharge, cough, and diarrhea). The calves remained healthy and exhibited no signs of illness during the experiment except mild diarrhea (2 calves) and were treated according to current standard operating procedures developed in consultation with the herd veterinarian and adopted on the University of British Columbia Dairy Education and Research Centre (Agassiz, BC, Canada).

\section{Sampling and Analysis}

Daily milk consumption, weekly starter, and hay intake (measured on 2 consecutive days each week) and weekly BW were measured throughout the experiment. Heart girth (circumference of the chest), body barrel (circumference of the belly before feeding), withers height (distance from base of the front feet to the withers), and hip height (distance from base of the rear feet to hook bones) measurements of the calves were recorded at d 3, 56 (weaning), and 70 (at the end of the experiment).

Milk samples were collected weekly for analysis by the Pacific Milk Analysis Laboratory Ltd. (Chilliwack, BC, Canada). Starter and hay samples were collected weekly and were sent to Cumberland Valley Analytical Service (Hagerstown, MD) to determine concentrations of DM, CP, ADF, Ca, P (AOAC, 2000), and NDF (Van Soest et al., 1991). Total digestible nutrients were calculated using NRC (2001) equations. The chemical composition of starter and hay provided to the calves over the experimental period is presented in Table 1 .

Blood samples (d 7, 21, 35, 49, and 63) were collected from the jugular vein and analyzed for glucose (Precision Xtra blood glucose kit; Abbott Diabetes Care, Alameda, CA) and BHBA (Precision Xtra blood ketone kit; Abbott Diabetes Care) concentrations using the procedures described by Iwersen et al. (2009) for blood ketone analysis.

At d 70, all bull calves were stunned using a captive bolt pistol and euthanized by exsanguination. Digestive tracts were collected, weighed, emptied, and rinsed with cold water and reweighed, and rumen tis- 
Table 1. Mean $( \pm \mathrm{SD})$ chemical composition of starter $^{1}$ and hay ${ }^{2}$

\begin{tabular}{lcc}
\hline $\begin{array}{l}\text { Composition } \\
(\% \text { of } D M)\end{array}$ & Starter & Hay \\
\hline $\mathrm{DM}$ & $89.5 \pm 0.62$ & $87.4 \pm 3.1$ \\
$\mathrm{CP}$ & $20.7 \pm 0.21$ & $17.7 \pm 2.34$ \\
$\mathrm{NDF}$ & $18.6 \pm 1.31$ & $62.4 \pm 2.66$ \\
$\mathrm{ADF}$ & $11.0 \pm 0.35$ & $34.8 \pm 1.59$ \\
$\mathrm{Ash}$ & $7.7 \pm 0.4$ & $9.1 \pm 1.1$ \\
$\mathrm{Ca}$ & $1.23 \pm 0.03$ & $0.37 \pm 0.09$ \\
$\mathrm{P}$ & $0.68 \pm 0.01$ & $0.29 \pm 0.05$ \\
$\mathrm{TDN}^{3}$ & 72.5 & 57.5 \\
\hline
\end{tabular}

${ }^{1}$ Textured calf starter (contains $57.5 \%$ concentrate pellets, $14 \%$ flatted barley, $13 \%$ flatted oats, $10 \%$ steamroll corn, and 3.5\% molasses; Unifeed Ltd., Chilliwack, BC, Canada).

${ }^{2}$ Chopped orchard grass hay (mean particle size $=1.2 \pm 0.4 \mathrm{~cm}$, calculated using Penn State Particle Separator).

${ }^{3}$ Total digestible nutrients were calculated using the equation given in NRC (2001).

sue samples were collected for analysis of papillae concentration, papillae length, papillae width, and rumen wall thickness according to Lesmeister et al. (2004). Rumen contents were squeezed using 3 layers of cheese cloth and rumen $\mathrm{pH}$ was measured immediately using a digital $\mathrm{pH}$ meter.

\section{Statistical Analysis}

Starter and total DMI (hay plus starter), BW, and blood metabolites (glucose and BHBA) data were analyzed using a repeated-measures mixed model (PROC MIXED; version 9.2; SAS Institute, Inc., Cary, NC) including calf as random component of the model and diet (ST and STH), age (wk), and their interaction as fixed components. The lowest Bayesian information criterion (BIC; fit statistic) level was used to select covariance structure of the model for each parameter. Data on starter intake, total DMI, and BW of calves were separately analyzed for wk 1 to 5 (higher milk supply period) and wk 6 to 10 (weaning and postweaning period). Treatment differences of structural growth (body barrel, heart girth, wither height, and hip height) data were evaluated by Student's $t$-test. Body and forestomach weight with or without digesta, rumen wall thickness, papillae concentration, length, and width data were analyzed using the Wilcoxon 2-sample test (version 9.2; SAS Institute, Inc.) because these responses were not normally distributed.

\section{RESULTS}

All calves consumed their daily milk allowance throughout the experiment. Intake of starter, hay, and total DM are presented in Figure 1. As expected, calves consumed little solid feed during the first 5 wk of life.
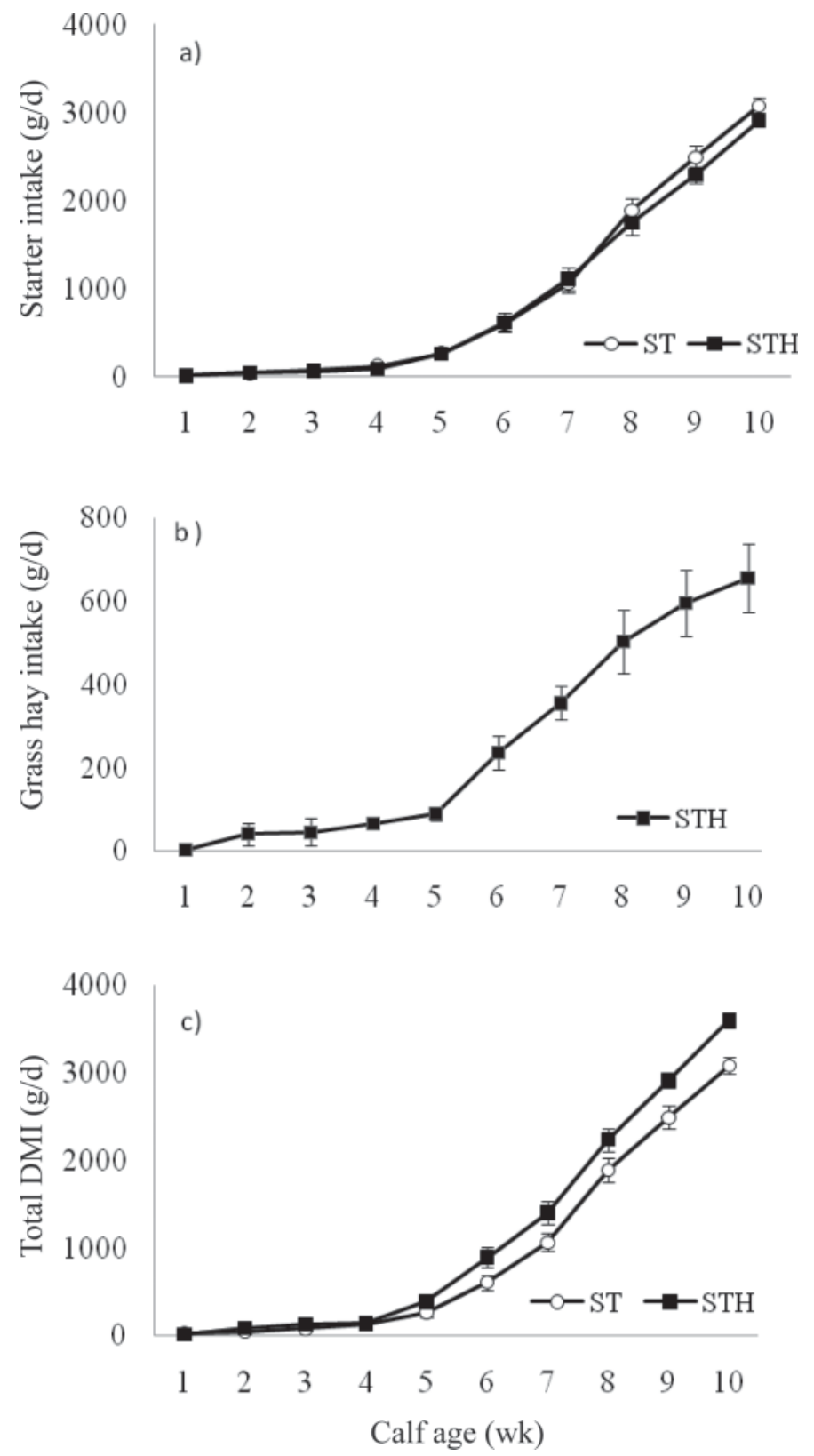

Figure 1. Mean $( \pm \mathrm{SE})$ weekly starter intake (a), grass hay intake (b) and total DMI (c). Values are shown separately for Holstein calves fed starter with $(\mathrm{STH} ; \mathrm{n}=15$ ) or without chopped grass hay (ST; n $=15$ ). All calves were offered $8 \mathrm{~L}$ of milk $/ \mathrm{d}$ from a nipple bottle from d 3 to $35,4 \mathrm{~L} / \mathrm{d}$ from d 36 to 53 , and $2 \mathrm{~L} / \mathrm{d}$ for the next $3 \mathrm{~d}$ before weaning at $\mathrm{d} 56$.

Intake of starter in ST calves and starter and hay in STH calves rapidly increased after d 35 when the milk supplied was decreased from 8 to $4 \mathrm{~L}$ per day, and increased further after weaning.

Starter consumption was similar for ST and STH calves during wk 1 to $5(P=0.80)$. Calves on the STH diet consumed some hay but maintained similar DMI 
Table 2. Mean hip height, body barrel, heart girth, and wither height of Holstein calves fed starter with (STH; $\mathrm{n}=15)$ or without chopped hay $(\mathrm{ST} ; \mathrm{n}=15)^{1}$

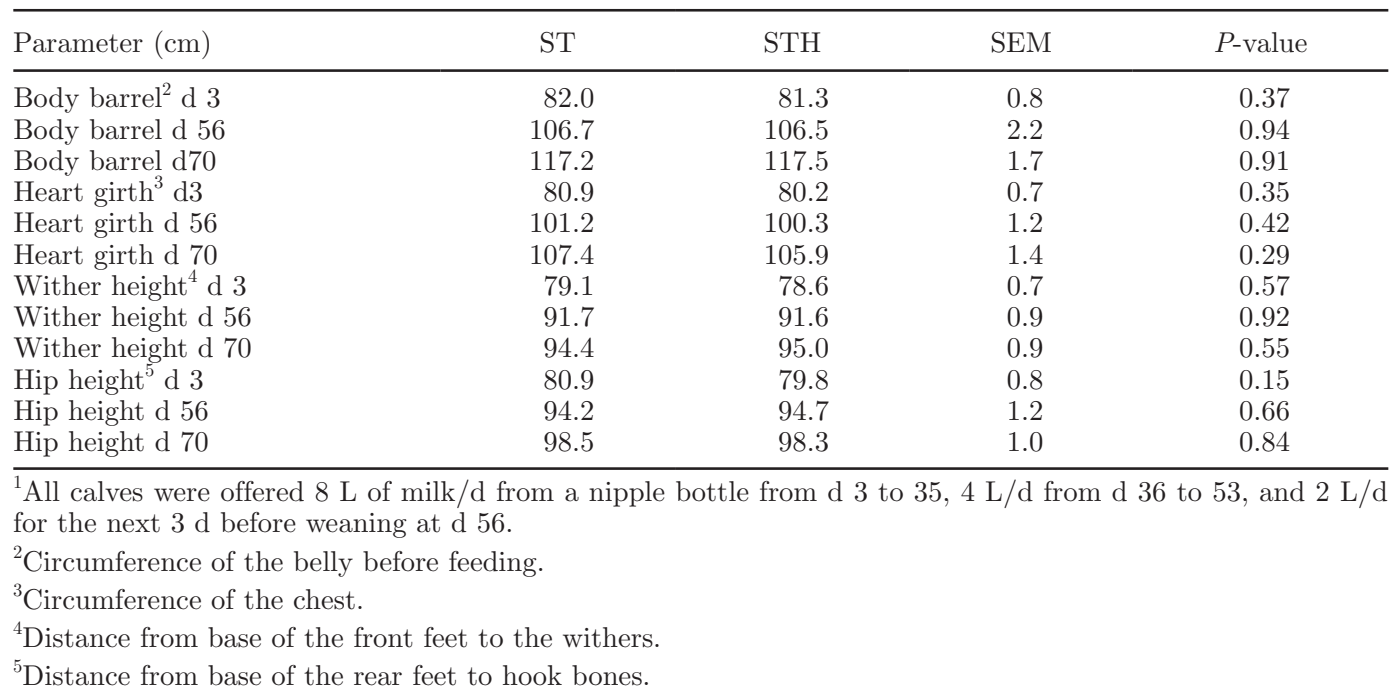

to ST calves during wk 1 to $5(P=0.21)$. The initial BW of calves on the ST and STH treatments were similar, with calves weighing, on average, $44.41 \pm 3.60 \mathrm{~kg}$. Body weight was not affected $(P=0.42)$ by the dietary treatment during wk 1 to 5 (Figure 2).

The ST calves tended to consume more starter than did STH calves during wk 6 to $10(P=0.10)$, but total solid DMI was higher for the STH calves during this period $(P=0.006)$. During wk 6 to 10 , STH calves tended to have higher BW than did ST calves $(P=$ 0.08 ; Figure 2). Over the entire experimental period

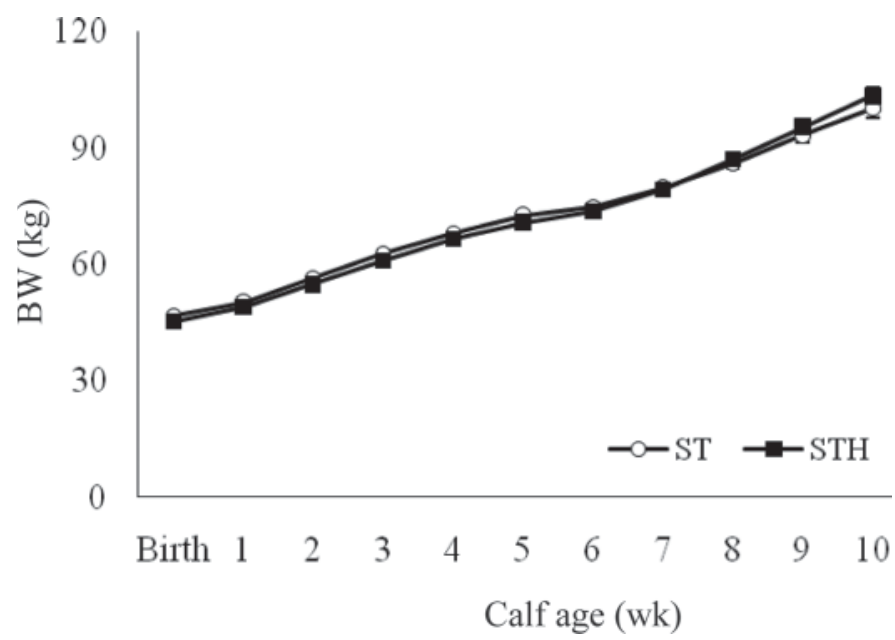

Figure 2. Mean $( \pm \mathrm{SE})$ weekly $B W$ of calves. Values are shown separately for Holstein calves fed starter with $(\mathrm{STH} ; \mathrm{n}=15)$ or without chopped grass hay (ST; $\mathrm{n}=15$ ). All calves were offered $8 \mathrm{~L}$ of $\mathrm{milk} / \mathrm{d}$ from a nipple bottle from d 3 to $35,4 \mathrm{~L} / \mathrm{d}$ from d 36 to 53 , and $2 \mathrm{~L} / \mathrm{d}$ for the next $3 \mathrm{~d}$ before weaning at $\mathrm{d} 56$. of $10 \mathrm{wk}$, the average daily BW gain was numerically higher for STH calves $(0.88 \mathrm{~kg} / \mathrm{d})$ compared with ST calves $(0.82 \mathrm{~kg} / \mathrm{d})$. On d 3,56 , and 70 no treatment differences for hip height, wither height, heart girth, and body barrel were observed $(P \geq 0.10$; Table 2$)$.

Body weight without rumen digesta was similar in ST and STH calves $(P=0.34$; Table 3$)$, with calves weighing, on average, $96.10 \pm 7.1 \mathrm{~kg}$ on d 70. Reticulorumen weights with $(P=0.02)$ and without $(P=0.03)$ digesta were heavier in STH calves compared with ST calves (Table 3). Omasum and abomasum weights with and without digesta were similar $(P=0.10)$ in ST and STH calves. Calves on ST and STH diets did not differ in rumen wall thickness $(P=0.87)$, papillae concentration $(P=0.36)$, papillae length $(P=0.87)$, and papillae width $(P=0.35)$. The mean rumen $\mathrm{pH}$ was higher $(P=0.002)$ in calves fed hay compared with those fed no forage.

The concentration of blood glucose decreased $(P=$ $0.0001)$ and blood BHBA concentration increased $(P$ $=0.0001)$ with calf age (Figure 3 ). Concentrations of blood glucose and blood BHBA were similar $(P=0.81$ and $P=0.18$, respectively) for the 2 treatments.

\section{DISCUSSION}

Higher milk rations can decrease solid feed intake before weaning, decreasing feed intake and growth in days after weaning (Jasper and Weary, 2002). In the present study, a rapid surge in solid feed consumption by calves after wk 5 can be ascribed to gradual weaning (Khan et al., 2007a; Sweeney et al., 2010). Increased consumption of starter and hay by calves as they aged 
Table 3. Forestomach weight with or without digesta, rumen $\mathrm{pH}$, wall thickness, and papillae length and width of 70 -d-old Holstein calves fed starter with $(\mathrm{STH} ; \mathrm{n}=5)$ or without chopped hay $(\mathrm{ST} ; \mathrm{n}=5)^{1}$

\begin{tabular}{lcccc}
\hline Parameter & ST & STH & SEM & $P$-value \\
\hline BW with rumen digesta (kg) & 104.8 & 104.5 & 5.97 & 0.82 \\
BW without rumen digesta (kg) & 98.58 & 93.60 & 4.93 & 0.34 \\
Organ weight with digesta (kg) & & & & \\
Rumen and reticulum & 7.99 & 12.7 & 1.56 & 0.02 \\
Omasum & 0.67 & 0.72 & 0.06 & 0.42 \\
Abomasum & 1.68 & 1.66 & 0.08 & 0.81 \\
Organ weight without digesta (kg) & & & & \\
Rumen and reticulum & 1.59 & 1.89 & 0.11 & 0.03 \\
Omasum & 0.43 & 0.48 & 0.04 & 0.23 \\
Abomasum & 0.48 & 0.47 & 0.04 & 0.71 \\
Papillae concentration (no./cm $\left.{ }^{2}\right)$ & 93.45 & 103.80 & 10.62 & 0.36 \\
Rumen wall thickness (cm) & 0.82 & 0.85 & 0.05 & 0.87 \\
Papillae length (cm) & 1.14 & 1.26 & 0.16 & 0.87 \\
Papillae width (cm) & 0.48 & 0.52 & 0.04 & 0.35 \\
Rumen pH & 5.06 & 5.49 & 0.10 & 0.002 \\
\hline
\end{tabular}

${ }^{1}$ All calves were offered $8 \mathrm{~L}$ of milk/d from a nipple bottle from d 3 to $35,4 \mathrm{~L} / \mathrm{d}$ from d 36 to 53 , and $2 \mathrm{~L} / \mathrm{d}$ for the next $3 \mathrm{~d}$ before weaning at $\mathrm{d} 56$.
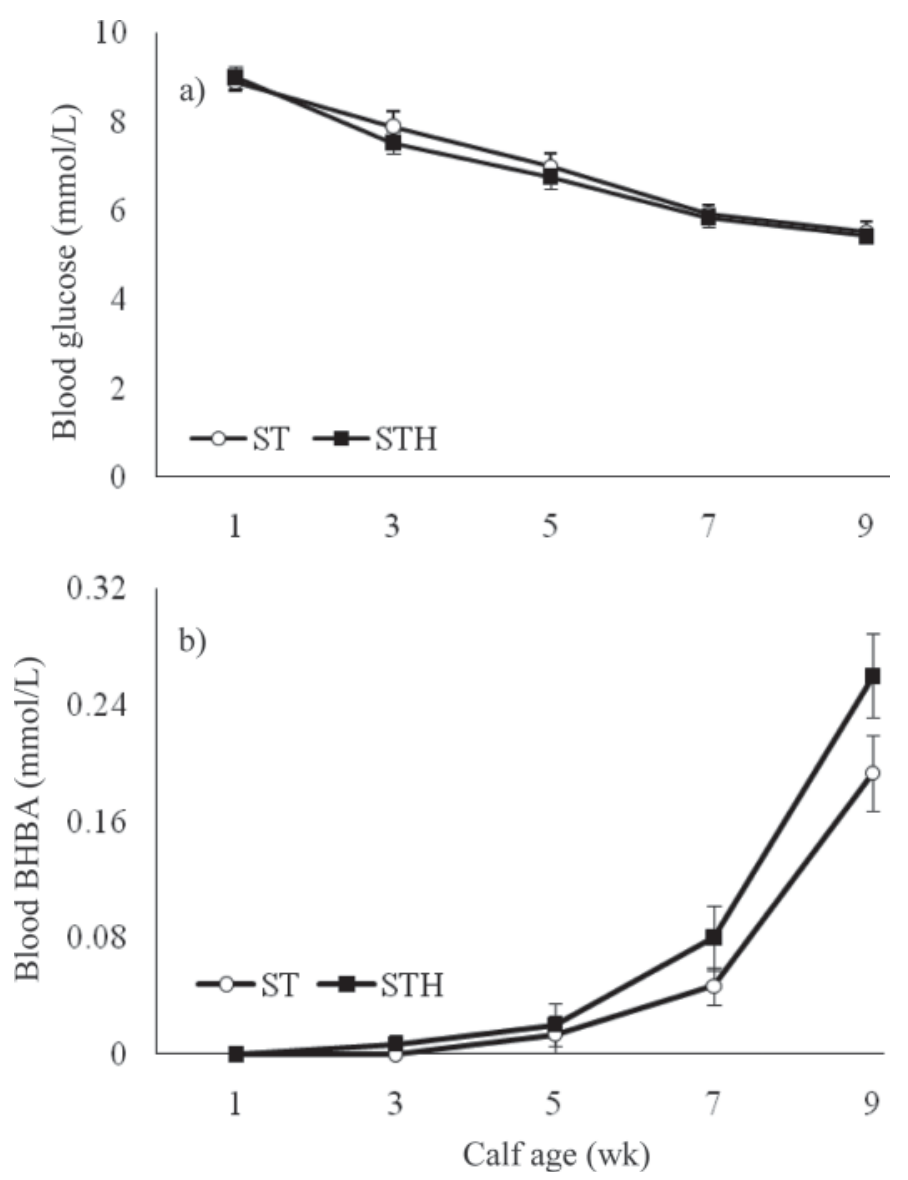

Figure 3. Mean ( \pm SE) blood glucose (a) and BHBA (b) concentrations of calves. Blood samples (wk 1, 3, 5, 7, and 9) were taken from the jugular vein. Values are shown separately for Holstein calves fed starter with (STH; $\mathrm{n}=15)$ or without chopped grass hay $(\mathrm{ST} ; \mathrm{n}=$ 15). All calves were offered $8 \mathrm{~L}$ of milk/d from a nipple bottle from d 3 to $35,4 \mathrm{~L} / \mathrm{d}$ from d 36 to 53 , and $2 \mathrm{~L} / \mathrm{d}$ for the next $3 \mathrm{~d}$ before weaning at $\mathrm{d} 56$ may be attributed to the increased capacity of their gut to accommodate and ferment solid feed (Baldwin et al., 2004; Drackley, 2008).

Provision of the higher milk rations combined with an underdeveloped rumen (both in physical capacity and microbial fermentation) during wk 1 to 5 likely prevented any effect of treatments on solid feed intake during this period. Differences between treatments in solid feed intake became apparent during wk 6 to 10 when milk supply was decreased. In contrast to previous studies (Hibbs et al., 1956; Leibholz, 1975; Hill et al., 2008a), the introduction of hay did not displace starter intake. This difference was likely because of calves in the current study eating much less solid food due to the greater availability of milk. The conventional supply of milk ( $\sim 10 \%$ of BW for first few weeks) does not provide enough nutrients to support the potential growth of neonatal Holstein calves (De Paula Vieira et al., 2008). Under these restricted feeding conditions, free choice hay may displace starter intake and decrease solid feed intake because of gut fill. The gradual weaning program used in the current study likely allowed for a gradual onset of rumen development (physical and metabolic capacity) in the final weeks of the milk feeding period (Khan et al., 2007a,b; Roth et al., 2009), promoting a relatively smooth transition from milk to solids under both treatments.

Increased intake of hay during wk 6 to 10 resulted in higher total solid feed intake by STH calves compared with ST calves, and likely contributed to the higher rumen $\mathrm{pH}$ observed in the STH calves. Negative effects of low rumen $\mathrm{pH}$ on intake have been demonstrated in mature cattle (Nocek et al. 1984; Yang et al., 2001) and developing calves (Suárez et al., 2006a). Greater feed intake by STH calves compared with ST calves is 
consistent with the findings of other studies (Stobo et al., 1966; Kincaid, 1980; Coverdale et al., 2004) showing increased solid feed consumption by calves when forage was added to the diet.

A trend toward higher BW gain during wk 6 to 10 in STH calves compared with ST calves may be attributed to greater solid feed intake by STH calves. These results are in agreement with the findings of Kincaid (1980) and Coverdale et al. (2004) who have reported greater BW with the inclusion of forage in the diets of calves.

For calves fed restricted quantities of milk (10 to $12 \%$ of BW), increases in BW associated with forage intake have been attributed to greater gut fill rather than carcass gain (Jahn et al., 1970, 1976; Hill et al., 2008a). Indeed, the inclusion of forage in the diets of calves is thought to decrease carcass gains because of nutrient dilution effects associated with the decreased energy density of the diet (as reviewed by Drackley, 2008). The results of the current study show that for calves fed more milk $(8 \mathrm{~L} / \mathrm{d}$ for the first 5 wk and gradually weaned over next 3 -wk period), forage does not decrease weight gain or rumen development. Despite the increases in the rumen weight with digesta in calves fed hay compared with those fed no hay, starter intake and BW of calves without rumen digesta were not affected by treatment. Furthermore, the circumference of the belly of the calves fed starter with or without hay were similar and the lack of any differences in hip height, wither height, and heart girth indicated that calves fed ST and STH diets grew at similar rate and achieved similar body size.

Greater empty rumen weight in STH calves compared with ST calves supports previous findings that large particle size and bulk of fibrous feed can provide mechanical stimuli to enhance rumen weight, its physical capacity, and volume in calves (Tamate et al., 1962; Suárez et al., 2006b; Khan et al., 2008). Similar rumen wall thickness, papillae concentration, length, and width values in calves fed hay or no hay could be ascribed to similar starter intake. Volatile fatty acids produced from the fermentation of ingested solids stimulate the development of ruminal papillae (concentration, length, and width) in young calves (Sander et al., 1959; Baldwin et al., 2004; Khan et al., 2008). Grain-based starter diets that promote production of VFA (specifically butyrate), and an associated low rumen $\mathrm{pH}$, are thought to trigger papillae growth in the rumen wall of calves (Stobo et al., 1966; Lesmeister et al., 2004). In our study, the calves on both treatments likely consumed sufficient starter to achieve normal rumen development.

Decreasing blood concentration of glucose and increasing blood BHBA concentration as calves aged indicated a shift in sources of physiological fuel during transition from liquid to solid diets. Similar concentrations of blood BHBA (an indicator of metabolic function of the rumen wall) in calves fed hay or no hay indicates that the rumen walls were equally efficient in converting butyrate to BHBA.

A higher rumen $\mathrm{pH}$ in STH calves compared with ST calves could be attributed to a shift in VFA concentration from propionate to acetate with dietary inclusion of hay (Zitnan et al., 1998; Suárez et al., 2006a,b). Generally, concentrate diets favor the proliferation and growth of starch digesters in the rumen, increasing butyrate and propionate production at the expense of acetate (Stobo et al., 1966; Dijkstra, 1994; Suárez et al., 2006a,b). In addition, the larger particle size of forages promotes salivary flow to the rumen through greater initial mastication and increased rumination (Hibbs et al., 1956; van Ackeren et al., 2009), likely contributing to higher rumen $\mathrm{pH}$ in $\mathrm{STH}$ calves.

Previous studies (Nocek et al., 1984; Suárez et al., 2006a,b) reported numerous negative effects (incidence of papillae branching, clumping of papillae, rumenitis, and even parakeratosis of rumen epithelium) of low $\mathrm{pH}$ in calves fed highly fermentable starter diets. We did not observe these problems in calves fed either diet, but encourage more work in this area.

\section{CONCLUSIONS}

Provision of chopped hay to calves fed high volumes of milk at an early age improved total solid feed intake and was beneficial for the physical development of the reticulorumen.

\section{ACKNOWLEDGMENTS}

The Animal Welfare Program is funded by the Natural Sciences and Engineering Research Council of Canada (NSERC) Industrial Research Chair Program (Ottawa, ON, Canada) with industry contributions from the Dairy Farmers of Canada (Ottawa, ON, Canada), Westgen Endowment Fund (Milner, BC, Canada), Pfizer Animal Health (Kirkland, QC, Canada), BC Cattle Industry Development Fund (Kamloops, BC, Canada), the BC Milk Producers (Burnaby, BC, Canada), BC Dairy Foundation (Burnaby, BC, Canada), BC Dairy Education and Research Association (Abbotsford, BC, Canada), and Alberta Milk (Edmonton, AB, Canada).

\section{REFERENCES}

AOAC. 2000. Official Methods of Analysis. 17th ed. Assoc. Off. Anal. Chem., Arlington, VA.

Baldwin, R. L., VI, K. R. McLeod, J. L. Klotz, and R. N. Heitmann. 2004. Rumen development, intestinal growth and hepatic metabo- 
lism in the pre- and post-weaning ruminant. J. Dairy Sci. 87(E Suppl.):E55-E65.

Brown, E. G., M. J. VandeHaar, K. M. Daniels, J. S. Liesman, L. T. Chapin, J. W. Forrest, R. M. Akers, R. E. Pearson, and M. S. Nielsen. 2005. Effect of increasing energy and protein intake on mammary development in heifer calves. J. Dairy Sci. 88:595-603.

CCAC (Canadian Council on Animal Care). 2009. CCAC Guidelines on the Care and Use of Farm Animals in Research, Teaching and Testing. Canadian Council on Animal Care, Ottawa, ON, Canada.

Coverdale, J. A., H. D. Tyler, J. D. Quigley III, and J. A. Brumm. 2004. Effect of various levels of forage and form of diet on rumen development and growth in calves. J. Dairy Sci. 87:2554-2562.

de Passillé, A. M. B., B. Sweeney, and J. P. Rushen. 2010. Crosssucking and gradual weaning of dairy calves. Appl. Anim. Behav. Sci. 124:11-15.

De Paula Vieira, A., V. Guesdon, A. M. de Passillé, M. A. G. von Keyserlingk, and D. M. Weary. 2008. Behavioural indicators of hunger in dairy calves. Appl. Anim. Behav. Sci. 109:180-189.

Diaz, M. C., M. E. Van Amburgh, J. M. Smith, J. M. Kelsey, and E. L. Hutten. 2001. Composition of growth of Holstein calves fed milk replacer from birth to 105-kilogram body weight. J. Dairy Sci. $84: 830-842$.

Dijkstra, J. 1994. Production and absorption of volatile fatty acids in the rumen. Livest. Prod. Sci. 39:61-69.

Drackley, J. K. 2008. Calf nutrition from birth to breeding. Vet. Clin. North Am. Food. Anim. Pract. 24:55-86.

Hibbs, J. W., H. R. Conrad, W. D. Pounden, and N. Frank. 1956. A high roughage system for raising calves based on early development of rumen function. VI. Influence of hay to grain ratio on calf performance, rumen development, and certain blood changes. J. Dairy Sci. 39:171-179.

Hill, T. M., H. G. Bateman, J. M. Aldrich, and R. L. Schlotterbeck. 2008a. Effects of the amount of chopped hay or cottonseed hulls in a textured calf starter on young calf performance. J. Dairy Sci. 91:2684-2693.

Hill, T. M., H. G. Bateman, J. M. Aldrich, and R. L. Schlotterbeck. 2008b. Effect of feeding different carbohydrate sources and amounts to young calves. J. Dairy Sci. 91:3128-3137.

Iwersen, M., U. Falkenberg, R. Voigtsberger, D. Forderung, and W. Heuwieser. 2009. Evaluation of an electronic cowside test to detect subclinical ketosis in dairy cows. J. Dairy Sci. 92:2618-2624.

Jahn, E., P. T. Chandler, and R. F. Kelly. 1976. Nutrient accumulation and prediction of body composition of 20-week old calves fed varying percentages of protein and fiber. J. Anim. Sci. 42:737-744.

Jahn, E., P. T. Chandler, and C. E. Polan. 1970. Effects of fiber and ratio of starch to sugar on performance of ruminating calves. J. Dairy Sci. 53:466-474.

Jasper, J., and D. M. Weary. 2002. Effects of ad libitum milk intake on dairy calves. J. Dairy Sci. 85:3054-3058.

Kertz, A. F., L. R. Prewitt, and J. P. Everett Jr. 1979. An early weaning calf program: Summarization and review. J. Dairy Sci. 62:1835-1843.

Khan, M. A., H. J. Lee, W. S. Lee, H. S. Kim, K. S. Ki, T. Y. Hur, G. H. Suh, S. J. Knag, and Y. J. Choi. 2007a. Structural growth, rumen development, metabolic and immune response of Holstein male calves fed milk through step-down and conventional methods. J. Dairy Sci. 90:3376-3387.

Khan, M. A., H. J. Lee, W. S. Lee, H. S. Kim, S. B. Kim, K. S. Ki, S. J. Park, J. K. Ha, and Y. J. Choi. 2007b. Starch source evaluation in calf starter: I. Feed consumption, body weight gain, structural growth, and blood metabolites in Holstein calves. J. Dairy Sci. 90:5259-5268.

Khan, M. A., H. J. Lee, W. S. Lee, H. S. Kim, S. B. Kim, S. B. Park, K. S. Baek, J. K. Ha, and Y. J. Choi. 2008. Starch source evalua- tion in calf starter: II. Ruminal parameters, rumen development, nutrient digestibilities, and nitrogen utilization in Holstein calves. J. Dairy Sci. 91:1140-1149.

Kincaid, R. L. 1980. Alternative methods of feeding alfalfa to calves. J. Dairy Sci. 63:91-94.

Leibholz, J. 1975. Ground roughage in the diet of the early-weaned calf. Anim. Prod. 20:93-100.

Lesmeister, K. E., P. R. Tozer, and A. J. Heinrichs. 2004. Development and analysis of a rumen tissue sampling procedure. J. Dairy Sci. $87: 1336-1344$.

Nocek, J. E. C. W. Heald, and C. E. Polan. 1984. Influence of ration physical form and nitrogen availability on ruminal morphology of growing bull calves. J. Dairy Sci. 67:334-343.

NRC. 2001. Nutrient requirement of dairy cattle. 7th rev. ed. National Research Council, National Academy Press, Washington, DC.

Roth, B. A., E. Hillmann, M. Stauffacher, and N. M. Keil. 2008. Improved weaning reduces cross-sucking and may improve weight gain in dairy calves. Appl. Anim. Behav. Sci. 111:251-261.

Roth, B. A., N. M. Keil, L. Gygax, and E. Hillmann. 2009. Influence of weaning method on health status and rumen development in dairy calves. J. Dairy Sci. 92:645-656.

Sander, E. G., H. N. Warner, H. N. Harrison, and J. K. Loosli. 1959. The stimulatory effect of sodium butyrate and sodium propionate on the development of rumen mucosa in the young calf. J. Dairy Sci. 42:1600-1605.

Stobo, I. J. F., J. H. B. Roy, and H. J. Gaston. 1966. Rumen development in the calf. Br. J. Nutr. 20:171-188.

Suárez, B. J., C. G. Van Reenen, G. Beldman, J. van Delen, J. Dijkstra, and W. J. J. Gerrits. 2006a. Effects of supplementing concentrates differing in carbohydrate composition in veal calf diets: I. Animal performance and rumen fermentation characteristics. J. Dairy Sci. 89:4365-4375.

Suárez, B. J., C. G. Van Reenen, W. J. J. Gerrits, N. Stockhofe, A. M. van Vuuren, and J. Dijkstra. 2006b. Effects of supplementing concentrates differing in carbohydrate composition in veal calf diets: II. Rumen development. J. Dairy Sci. 89:4376-4386.

Sweeney, B. C., J. P. Rushen, D. M. Weary, and A. M. B. de Passillé 2010. Duration of weaning, starter intake, and weight gain of dairy calves fed large amounts of milk. J. Dairy Sci. 93:148-152.

Tamate, H., A. D. McGilliard, N. L. Jacobson, and R. Getty. 1962 Effect of various dietaries on the anatomical development of the stomach in the calf. J. Dairy Sci. 45:408-420.

van Ackeren, C., H. Steingaß, K. Hartung, R. Funk, and W. Drochner. 2009. Effect of roughage level in a total mixed ration on feed intake, ruminal fermentation patterns and chewing activity of earlyweaned calves with ad libitum access to grass hay. Anim. Feed Sci. Technol. 153:48-59.

Van Soest, P. J., J. B. Robertson, and B. A. Lewis. 1991. Methods for dietary fiber, neutral detergent fiber, and nonstarch polysaccharides in relation to animal nutrition. J. Dairy Sci. 74:3583-3597.

Vickers, K. J., L. Niel, L. M. Kiehlbauch, and D. M. Weary. 2005. Calf response to caustic paste and hot-iron dehorning using sedation with and without local anesthetic. J. Dairy Sci. 88:1454-1459.

Yang, W. Z., K. A. Beauchemin, and L. M. Rode. 2001. Effects of grain processing, forage to concentrate ratio, and forage particle size on rumen $\mathrm{pH}$ and digestion by dairy cows. J. Dairy Sci. 84:2203-2216.

Zitnan, R., J. Voigt, U. Schönhusen, J. Wegner, M. Kokardová, H. Hagemeister, M. Levkut, S. Kuhla, and A. Sommer. 1998. Influence of dietary concentrate to forage ratio on the development of rumen mucosa in calves. Arch. Tierernähr. 51:279-291. 